\title{
Rancang Bangun Trainer Friction Loss Pada Sistem Perpipaan Sebagai Media Pembelajaran Di Laboratorium Mekanika Fluida Pada Jurusan Teknik Mesin Unesa
}

\author{
Diastian Vinaya Wijanarko $^{1}$, I Made Arsana ${ }^{2}$, Bellina Yunitasari ${ }^{3}$ \\ 1,2,3 Jurusan Teknik Mesin, Universitas Negeri Surabaya \\ diastianwijanarko@unesa.ac.id \\ madearsana@unesa.ac.id \\ bellinayunitasari@unesa.ac.id
}

\begin{abstract}
ABSTRAK
Rancang bangun trainer friction loss pada sistem perpipaan telah selesai di uji pada penelitian ini. Bahan pipa terbuat dari westpex, tekanan air diukur dengan menggunakan pressure gauge, pengukur debit menggunakan flow meter. Pengkuran akan dilakukan pada bukaan katub seperempat, setengah, tigaperempat, dan penuh. Hasil pengujian alat akan diolah kedalam bentuk head loss, pressure loss, kecepatan aliran, bilangan Reynolds, dan koefisien gesek pipa. Berdasarkan hasil yang telah dicapai, kesimpulan yang didapatkan adalah head loss meberikan hasil semakin meningkat pada bukaan katub setengah sampai penuh, pressure loss memberikan hasil yang semakin meningkat pada bukaan katub seperempat sampai penuh, kecepatan aliran aliran pada bukaan katub seperempat sampai penuh semakin besar sehingga bilangan Reynolds meningkat mengikuti besarnya bilangan Reynold, dan koefisien gesek pipa pada setiap bukaan katub seperempat sampai penuh menurun.
\end{abstract}

Kata Kunci: bukaan katub, gesekan, pipa, sambungan pipa, trainer

\begin{abstract}
The design of the friction loss trainer in the piping system has been tested in this study. The pipe material is made of westpex, a water pressure was measured by using a pressure gauge, a flow meter using a flow meter. Measuring will be done at quarter, half, three quarter, and full valve openings. The test results of the tool will be processed into head loss, pressure loss, flow velocity, Reynolds number, and pipe friction coefficient. Based on the results that have been achieved, the conclusions obtained are head loss giving results increasing in the opening of the valve half to full, pressure loss results in an increasing number of openings in the quarter to full, the flow velocity at the opening of the quarter to full valve is greater so that the number Reynolds increase following the magnitude of the Reynold number, and the pipe friction coefficient at each quarter valve opening until full decreases.
\end{abstract}

Keywords: valve opening, friction, pipe, pipe connection,

trainer 


\section{PENDAHULUAN}

Perkembangan teknologi saat ini tidak terlepas dari perkembangan ilmu mekanika fluida. Salah satu teknologi yang menggunakan konsep tentang aliran fluida adalah sistem perpipaan. Prinsip kerja dari pipa adalah mengalirkan sebuah fluida dari satu tempat ke tempat lain. Keinginan dari perancang sistem perpipaan adalah mampu mengalirkan suatu fluida dengan menggunakan energi pompa yang sedikit dan desain yang sederhana. Disisi lain fluida memiliki sifat-sifat yang dapat memengaruhi kualitas dan kuantitas dari aliran fluida pada pipa itu sendiri. Salah satu permasalahan yang sering dihadapi dalam sistem perpipaan adalah kerugian tekanan akibat gesekan antara fluida dan pipa serta kerugian akibat adanya sambungan pipa (fitting). Oleh karena itu dibutuhkan suatu konsep untuk memahami sifatsifat dalam aliran fluida.

Berdasarkan penjelasan diatas, diperlukan suatu pendekatan khusus untuk mengetahui besarnya kualitas dan kuantitas dari suatu aliran fluida. Salah satu konsep untuk menganalisa aliran dalam pipa adalah dengan menggunakan konsep aliran internal incompresible. Menurut konsep aliran internal incompresible terdapat beberapa aspek yang harus dipahami untuk menganalisa aliran dalam pipa, yaitu: bilangan reynold, debit, faktor gesekan, viskositas, pressure loss, dan head loss.

Perguruan tinggi sebagai institusi tertinggi dalam jenjang kependidikan, merupakan sebuah institusi yang berfungsi untuk menyiapkan peserta didik menjadi sumber daya manusia yang memiliki kemampuan penguasaan akademik dan dapat mengembangkan ilmu pengetahuan yang dimiliki pada kehidupan masyarakat dan dunia industri. Oleh karena itu, sistem pendidikan di perguruan tinggi harus sejalan dengan perkembangan IPTEK bagi masyarakat dan kebutuhan di industri saat ini. Sehingga lulusan perguruan tinggi dapat menjadi sumber daya manusia yang kompeten dibidangnya dan memiliki standar keahlian yang dibutuhkan oleh masyarakat serta industri. Universitas Negeri Surabaya khususnya Jurusan Teknik Mesin, Fakultas Teknik memiliki keterkaitan erat dengan pengembangan ilmu pengembangan IPTEK bagi masyarakat dan industri.

Mata kuliah Mekanika Fluida adalah mata kuliah yang mempelajari tentang sifat-sifat dan konsep analisa aliran fluida. Salah satu materi mata kuliah tersebut adalah mempelajari tentang sifat dan konsep aliran fluida aliran internal. Pengetahuan tentang aliran internal fluida sangat berguna dalam aplikasi perpipaan baik dalam bidang industri, pengairan di daerah perkebunan, gedung bertingkat, rumah tangga, dan lain-lain. Melalui mata kuliah tersebut dijelaskan bagaimana cara menganalisa kerugian tekanan dalam sistem perpipaan baik akibat gesekan antara fluida dan pipa maupun akibat sambungan (fitting). Selama ini materi mata kuliah mekanika fluida masih dilaksanakan dengan menggunakan metode ceramah dan diskusi, dimana mahasiswa hanya mendapatkan materi mata kuliah berdasarkan pemahaman secara teori. Untuk meningkatkan pemahaman mahasiswa dibutuhkan sebuah media pembelajaran tambahan untuk menganalisa permasalahan secara langsung, salah satunya adalah dengan menggunakan alat praktikum berupa trainer.

Berdasarkan penjelasan diatas peneliti mencoba untuk membuat rancang bangun alat trainer friction losses pada perpipaan sehingga diharapkan dengan perancangan alat tersebut dapat meningkatkan pemahaman mahasiswa tentang ilmu mekanika fluida terutama perhitungan gaya pada perpipaan.

\section{METODOLOGI PENELITIAN}

\section{Desain Alat Trainer Friction Loss pada Sistem Perpipaan}

Rangka pada alat trainer terbuat dari besi siku, papan tempat pipa melekat terbuat dari akrilik, dan 
pipa terbuat dari pipa westpex. Pengukuran rangka, akrilik dan pipa dilakukan dengan menggunakan meteran sesuai dengan desain yang telah ditetapkan. Setelah mendapatkan ukuran yang diinginkan, besi siku dilas sesuai dengan bentuk yang telah diteteapkan, kemudian papan akrilik

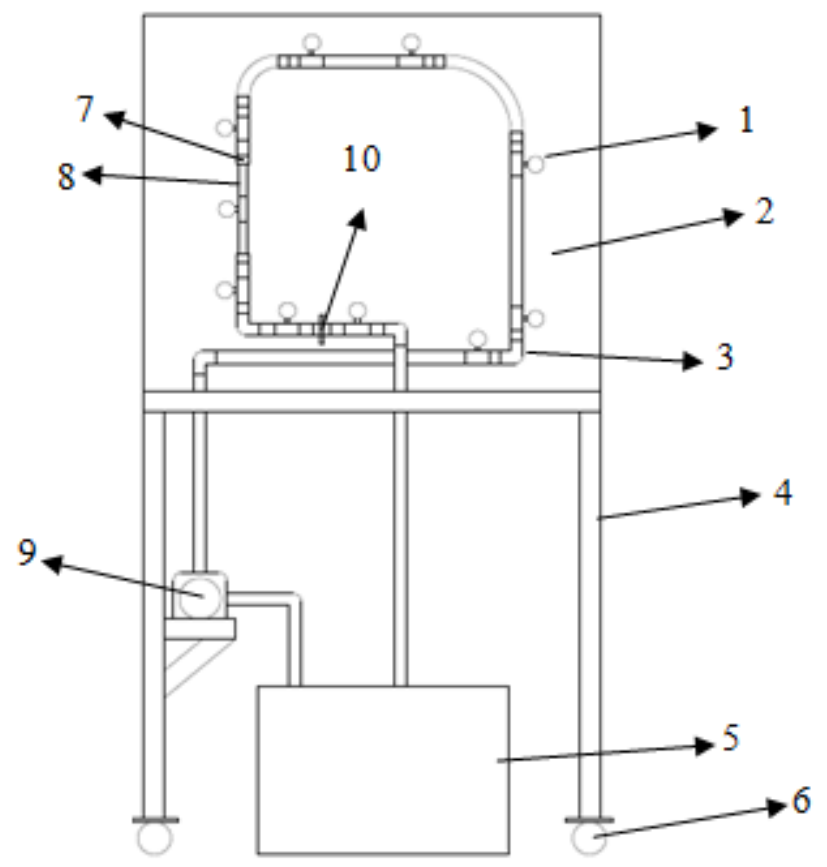

Gambar 1. Tampak depan trainer friction loss pada sistem perpipaan dipotong sesuai dengan dudukan rangka sebagai dudukan tempat pipa melekat. Gambar rancang bangun alat trainer tampak depan dan tampak samping dapat dilihat pada gambar 1 dan gambar 2 dibawah.

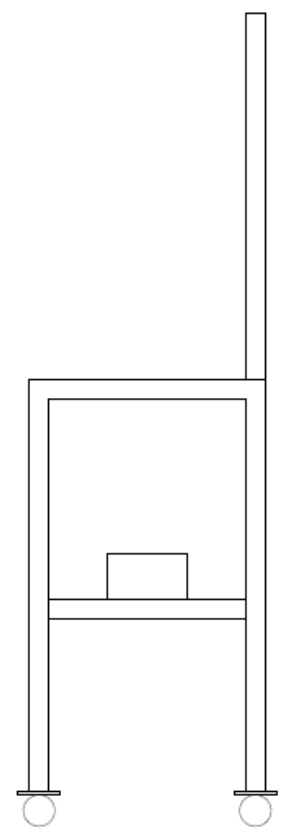

Gambar 2. Tampak Samping trainer friction loss pada sistem perpipaan

Keterangan:

1. Pressure gauge

2. Papan Akrilik

3. Sambungan elbow $90^{\circ}$

4. Rangka terbuat dari besi siku

5. Bak Air

6. Roda troli

7. Sambungan overloud

8. Pipa westpex

9. Pompa air

10. Katub Air (Valve)

Ilustrasi untuk pengujian ditunjukkan pada gambar 5. Tanda panah merah menunjukkan arah aliran 
fluida, notasi nomor satu sampai dengan sepuluh menunjukkan alat pressure gauge sebagai pengukur tekanan. Prosedur percobaan ditunjukkan dengan cara sebagai berikut:

1. Menghubungkan instalasi uji dengan tangki menggunakan pipa yang telah disediakan.

2. Menjalankan pompa kemudian perlahanlahan buka katup pada tangki untuk mengatur laju aliran. Laju aliran diatur dengan bukaan katub sebesar penuh, 3/4, 1/2, $1 / 4$.

3. Menghitung laju aliran dengan mencari debit.

4. Mencatat penunjukan alat ukur tekanan air (pressure gauge).

5. Menghitung head loss, pressure loss, kecepatan aliran, angka Reynolds, dan koefisien gesek pipa.

6. Dari hasil perhitungan membuat tabel karakteristik aliran untuk setiap obyek pengamatan.

7. Buat kurva karakteristik antara titik- titik pengukuran.

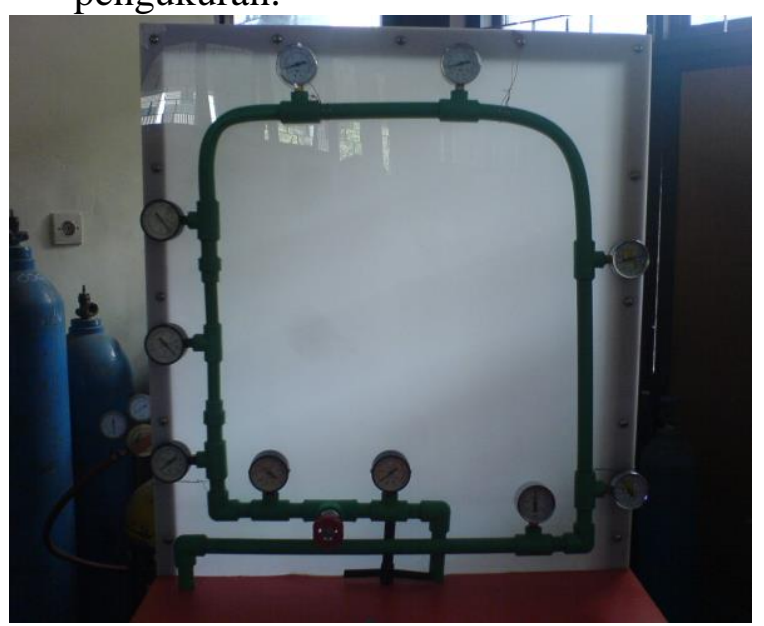

Gambar 3. Pressure gauge trainer friction loss pada sistem perpipaan

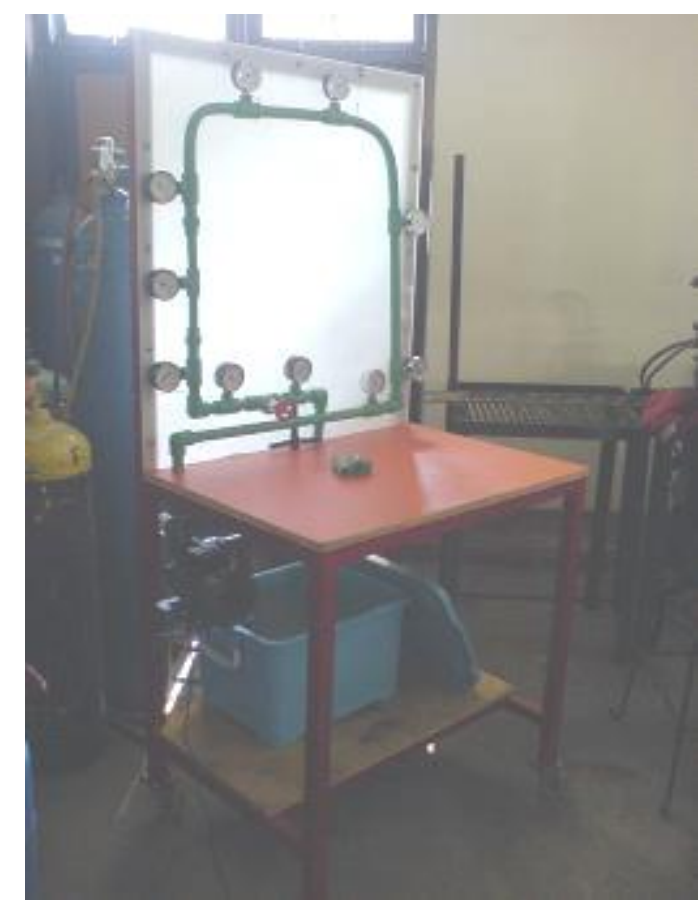

Gambar 4. Trainer friction loss pada sistem perpipaan yang sudah jadi

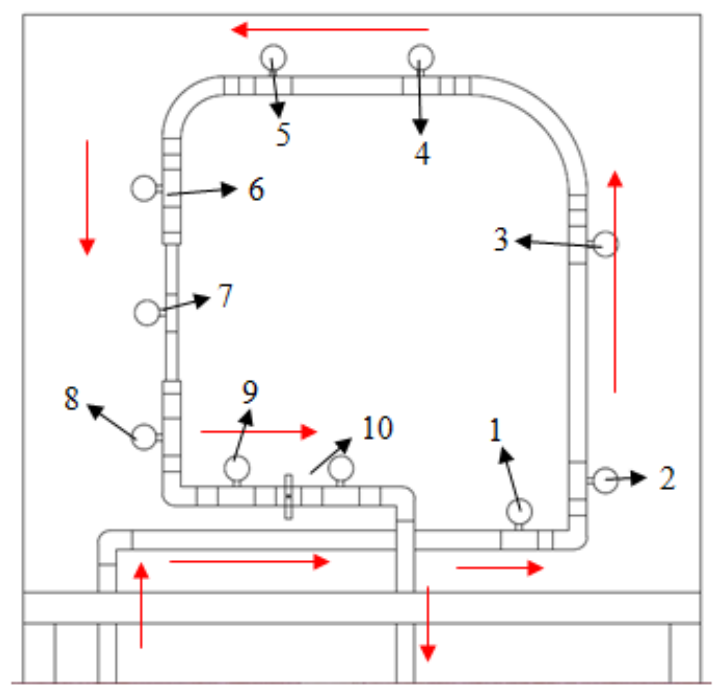

Gambar 5 Ilustrasi arah aliran pada pipa

\section{Persamaan yang Digunakan pada Trainer}

- Bilangan Reynolds

Kecepatan aliran sangat dibutuhkan untuk mencari besarnya bilangan reynold, kecepatan tersebut 
dapat dicari dengan menggunakan persamaan sebagai berikut:

$$
\text { - } u=\frac{4 Q}{\pi D^{2}}(\mathrm{~m} / \mathrm{s})
$$

Dimana:

- $\quad \mathrm{u}=\operatorname{kecepatan}(\mathrm{m})$

- $\mathrm{Q}=\operatorname{debit}\left(\frac{m^{3}}{s}\right)$

- $\quad \mathrm{D}=$ diameter pipa $(\mathrm{m})$

- Setelah itu, bilangan reynold didapatkan dengan menggunakan rumus:

$\operatorname{Re}=\frac{\mathrm{uD}}{v}$

- Koefisien Gesek

$\frac{1}{\sqrt{f}}=-1,8 \log \left[\left(\frac{\varepsilon / D}{3,7}\right)^{1.11}+\frac{6,9}{\operatorname{Re}}\right]$

- Head Loss

$\mathrm{H}_{\mathrm{L} \text { major }}=f \frac{\ell}{D} \frac{\rho V^{2}}{2 g}$

- Pressure loss

$p_{1}-p_{2}=\gamma\left(\mathrm{z}_{2}-\mathrm{z}_{1}\right)+f \frac{\ell}{D} \frac{\rho V^{2}}{2}$

\section{PEMBAHASAN}

\section{Desain Trainer}

Desain trainer alat friction loss pada sistem perpipaan dimulai dengan menggambar sebuah dengan menggunakan baut dan mur. Proses selanjutnya adalah mengecat rangka trainer dengan menggunakan cat besi. sketsa dengan menggunakan software menggambar. Setelah sketsa dan ukuran didapatkan, langkah berikutnya adalah membuat trainer. Besi siku dipotong dengan menggunakan gerinda potong sesuai dengan ukuran sketsa rencana. Setelah diperoleh potongan yang sesuai, maka langkah selanjutnya adalah menyambung potongan besi tersebut dengan menggunakan las listrik hingga menjadi rangka. Langkah selanjutnya adalah membuat papan dudukan pipa dengan menggunakan akrilik. Pada proses ini papan dipotong dengan menggunakan gergaji sesuai dengan ukuran yang telah direncanakan, kemudian papan akrilik disatukan pada rangka besi siku Pemasangan pipa dilakukan dengan mengelas pipa kemudian memasang sambungan pipa berupa elbow, katub gate dan menempatkan pressure gauge disetiap titik yang sudah ditentukan. Setelah proses penyambungan pipa selesai, maka silakukan pemasangan pompa dan bak penampung air. Pemasangan alat trainer sudah selesai dilakukan, langkah berikutnya adalah menguji alat.

\section{Bilangan Reynold}

Langkah pertama dalam menguji alat trainer adalah dengan menghitung bilangan Reynold. Bukaan katub diatur sesuai dengan yang diiginkan, kemudian setiap bukaan katub diukur kecepatannya dengan flow meter

Tabel 1. Hasil Pengukuran Debit, Kecepatan, dan Bilangan Reynold

\begin{tabular}{|l|l|l|l|l|}
\hline No. & $\begin{array}{l}\text { Bukaan } \\
\text { Katub }\end{array}$ & $\begin{array}{l}\text { Debit } \\
\left(\mathbf{m}^{3} / \mathbf{s}\right)\end{array}$ & $\begin{array}{l}\text { Kecepatan } \\
(\mathbf{m} / \mathbf{s})\end{array}$ & $\begin{array}{l}\text { Bilangan } \\
\text { Reynold }\end{array}$ \\
\hline 1 & Penuh & 0.004 & 7.90 & $99,906.31$ \\
\hline 2 & $\begin{array}{l}\text { Tiga } \\
\text { perempat }\end{array}$ & 0.0036 & 7.11 & $89,915.68$ \\
\hline 3 & Setengah & 0.0027 & 5.33 & $67,436.76$ \\
\hline
\end{tabular}




\begin{tabular}{|l|l|l|l|l|}
4 & Seperempat & 0.002 & 3.95 & $49,953.15$ \\
\hline
\end{tabular}

Debit dan Bilangan Reynold Disetiap Bukaan Katub

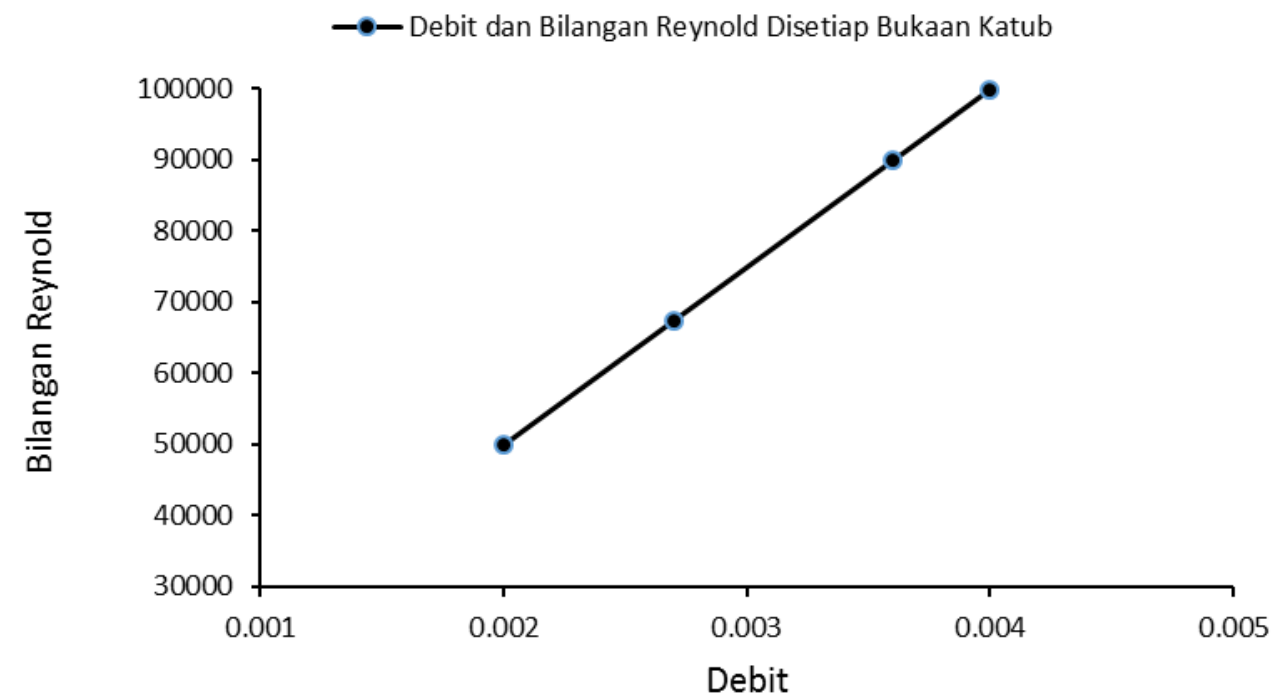

Gambar 6. Grafik Bilangan Reynold pada Tiap Bukaan Katub

\subsection{Head Loss}

Head loss adalah suatu nilai untuk mengetahui seberapa besarnya reduksi tekanan total (total head) yang diakibatkan oleh fluida saat melewati sistem pengaliran. Head loss dibedakan menjadi dua, yaitu head loss major dan head loss minor. Head loss major berkaitan dengan panjang pipa lurus dan kondisi fully developed, sedangkan head loss minor berkaitan dengan profil pipa. Perhitungan dimulai dari pipa elbow $90^{\circ}$ dimana terdapat pressure gauge, kemudian diteruskan mengikuti profil pipa dengan urutan perhitungan ditunjukkan pada gambar 7 .

Tabel 2 Perhitungan $\mathrm{K}_{\mathrm{L}}$, Pressure Drop, kecepatan dan Head Loss pada setiap bukaan katub

\begin{tabular}{|c|c|c|c|c|c|c|c|c|c|c|c|c|c|c|c|c|c|}
\hline \multirow[t]{2}{*}{ No } & \multirow[t]{2}{*}{ Jenis Pipa } & \multicolumn{4}{|c|}{$\begin{array}{c}\text { Bukaan katub } \\
\text { penuh }\end{array}$} & \multicolumn{4}{|c|}{$\begin{array}{c}\text { Bukaan katub } \\
\text { tigaperempat }\end{array}$} & \multicolumn{4}{|c|}{$\begin{array}{c}\text { Bukaan katub } \\
\text { setengah }\end{array}$} & \multicolumn{4}{|c|}{$\begin{array}{c}\text { Bukaan katub } \\
\text { seperempat }\end{array}$} \\
\hline & & KL & $\Delta \mathrm{P}$ & $\mathbf{U}$ & $\mathbf{h}_{\mathrm{L}}$ & KL & $\Delta \mathrm{P}$ & $\mathbf{U}$ & $\mathbf{h}_{\mathrm{L}}$ & KL & $\Delta \mathrm{P}$ & $\mathbf{U}$ & $\mathbf{h}_{\mathrm{L}}$ & KL & $\Delta \mathrm{P}$ & $\mathbf{U}$ & $\mathbf{h}_{\mathrm{L}}$ \\
\hline 1 & Elbow $90^{\circ}$ & 0.3 & 0.4 & 7.90 & 0.95 & 0.3 & 0.4 & 5.33 & 0.43 & 0.3 & 0.4 & 5.33 & 0.43 & 0.3 & 0.5 & 3.95 & 0.25 \\
\hline 2 & Long Bend $90^{\circ}$ & 0.12 & 0.3 & 7.25 & 0.32 & 0.12 & 0.3 & 4.32 & 0.11 & 0.12 & 0.3 & 4.32 & 0.11 & 0.12 & 0.3 & 2.41 & 0.03 \\
\hline 3 & Straight Pipe & 0 & 0.2 & 7.23 & 0.40 & 0 & 0.2 & 4.29 & 0.14 & 0 & 0.2 & 4.29 & 0.14 & 0 & 0.4 & 2.37 & 0.04 \\
\hline 4 & Short Bend $90^{\circ}$ & 0.09 & 0.1 & 7.27 & 0.24 & 0.09 & 0.3 & 4.36 & 0.09 & 0.09 & 0.3 & 4.36 & 0.09 & 0.09 & 0.2 & 2.49 & 0.03 \\
\hline 5 & \begin{tabular}{|l} 
Sudden \\
Contraction
\end{tabular} & 0.25 & 0.4 & 7.37 & 0.69 & 0.25 & 0.4 & 4.54 & 0.26 & 0.25 & 0.4 & 4.54 & 0.26 & 0.25 & 0.4 & 2.79 & 0.09 \\
\hline 6 & $\begin{array}{l}\text { Sudden } \\
\text { Expansion }\end{array}$ & 0.25 & 0.5 & 7.46 & 0.71 & 0.25 & 0.3 & 4.67 & 0.28 & 0.25 & 0.3 & 4.67 & 0.28 & 0.25 & 0.5 & 2.99 & 0.11 \\
\hline 7 & Elbow $90^{\circ}$ & 0.11 & 0.3 & 7.58 & 0.32 & 0.11 & 0.2 & 4.82 & 0.13 & 0.11 & 0.2 & 4.82 & 0.13 & 0.11 & 0.2 & 3.22 & 0.06 \\
\hline
\end{tabular}


\begin{tabular}{|l|l|l|l|l|l|l|l|l|l|l|l|l|l|l|l|l|l|}
\hline 8 & Valve & 0.15 & 0.2 & 7.63 & 0.44 & 0.15 & 0.1 & 4.90 & 0.18 & 0.15 & 0.1 & 4.90 & 0.18 & 0.15 & 0.1 & 3.34 & 0.08 \\
\hline
\end{tabular}

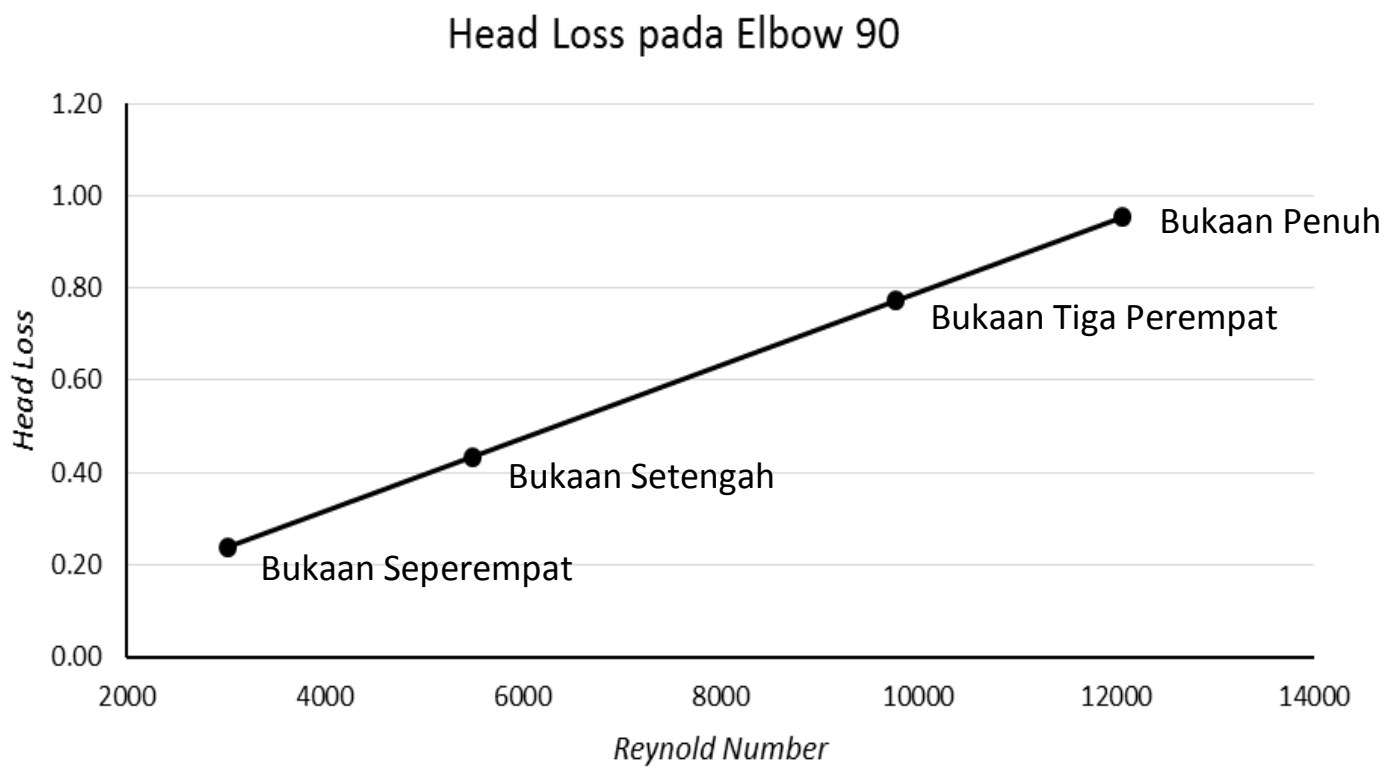

Gambar 7. Grafik Head Loss pada Elbow $90^{\circ}$

\subsection{Koefisien Gesek}

Perhitungan koefisien gesek dapat dilakukan dengan menggunakan persamaan Haaland.

Tabel 3 Perhitungan Bilangan Reynold, dan koefisien friksi pada setiap bukaan katub

\begin{tabular}{|c|c|c|c|c|c|c|c|c|c|c|c|c|c|}
\hline \multirow[t]{2}{*}{ No } & \multirow[t]{2}{*}{ Jenis Pipa } & \multicolumn{3}{|c|}{ Bukaan katub penuh } & \multicolumn{3}{|c|}{$\begin{array}{c}\text { Bukaan katub tiga } \\
\text { perempat }\end{array}$} & \multicolumn{3}{|c|}{ Bukaan katub setengah } & \multicolumn{3}{|c|}{$\begin{array}{c}\text { Bukaan katub } \\
\text { seperempat }\end{array}$} \\
\hline & & $\mathbf{U}$ & Reynold & $f$ & $\mathbf{U}$ & Reynold & $f$ & $\mathbf{U}$ & Reynold & $f$ & $\mathbf{U}$ & Reynold & $f$ \\
\hline 1 & Elbow $90^{\circ}$ & 7.90 & 99930.28 & 0.00336 & 7.11 & 89937.25 & p.00344 & 5.33 & 67436.76 & 0.00366 & 3.95 & 49953.15 & 0.00391 \\
\hline 2 & $\begin{array}{ll}\text { Long } & \text { Bend } \\
90^{\circ} & \end{array}$ & 7.25 & 91708.17 & 0.00342 & 6.40 & 80955.63 & 0.00352 & 4.32 & 54596.25 & 0.00383 & 2.41 & 30468.87 & 0.00438 \\
\hline 3 & Straight Pipe & 7.23 & 91455.18 & 0.00343 & 6.39 & 80774.07 & 0.00352 & 4.29 & 54326.67 & 0.00383 & 2.37 & 29983.14 & 0.00440 \\
\hline 4 & $\begin{array}{|ll|}\text { Short } & \text { Bend } \\
90^{\circ} & \end{array}$ & 7.27 & 91961.16 & 0.00342 & 6.43 & 81359.12 & p.00351 & 4.36 & 55192.79 & 0.00382 & 2.49 & 31525.32 & 0.00435 \\
\hline 5 & $\begin{array}{l}\text { Sudden } \\
\text { Contraction }\end{array}$ & 7.37 & 93226.10 & 0.00341 & 6.55 & 82904.53 & p.00350 & 4.54 & 57446.48 & 0.00379 & 2.79 & 35322.79 & 0.00423 \\
\hline 6 & \begin{tabular}{|l|} 
Sudden \\
Expansion \\
\end{tabular} & 7.46 & 94364.54 & 0.00340 & 6.64 & 84052.99 & p.00349 & 4.67 & 59091.82 & 0.00376 & 3.00 & 37940.00 & 0.00416 \\
\hline 7 & Elbow $90^{\circ}$ & 7.58 & 95882.47 & 0.00339 & 6.75 & 85362.11 & p.00348 & 4.82 & 60939.53 & 0.00374 & 3.22 & 40758.17 & 0.00409 \\
\hline 8 & Valve & 7.63 & 96514.94 & 0.00339 & 6.81 & 86106.29 & 0.00347 & 4.90 & 61977.66 & 0.00372 & 3.34 & 42294.58 & 0.00406 \\
\hline
\end{tabular}




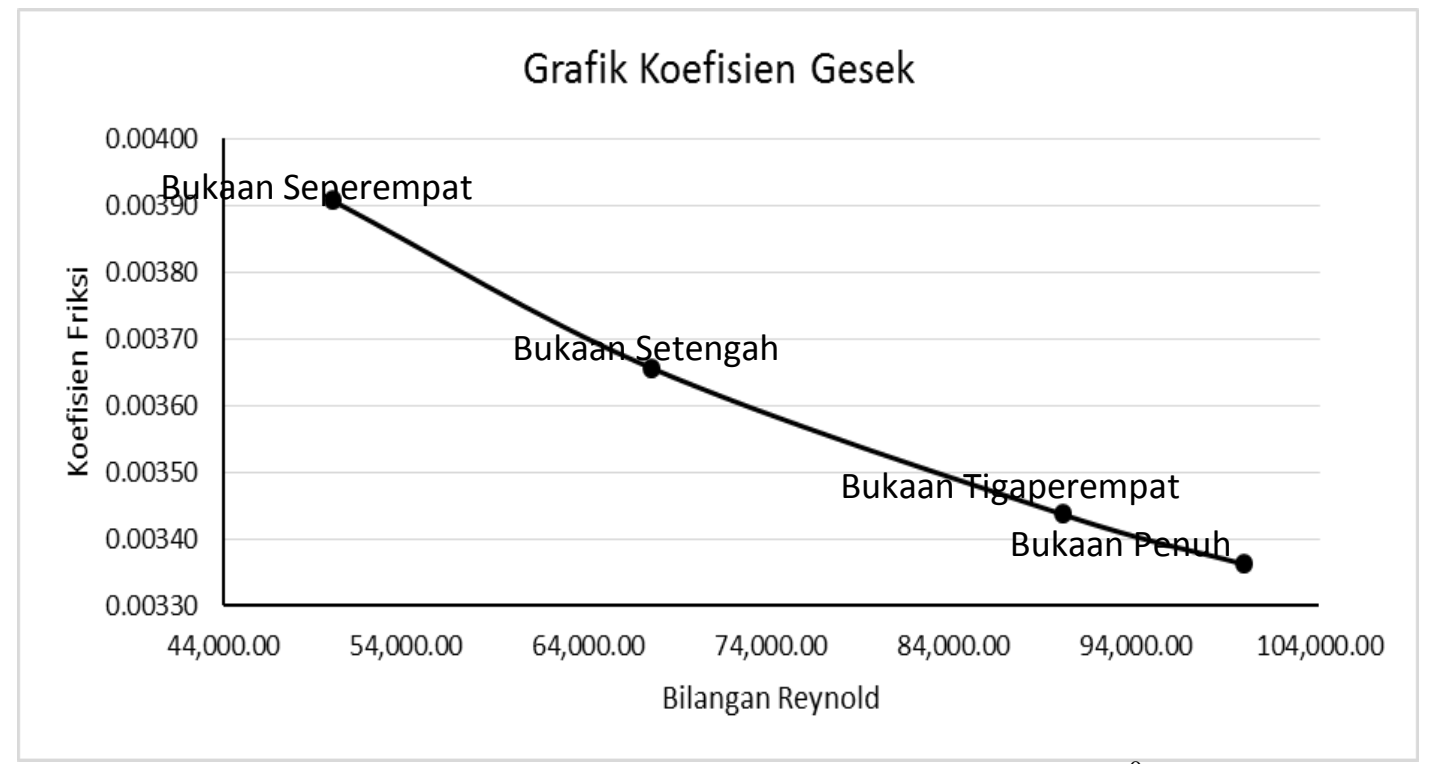

Gambar 8 Grafik Koefisien Gesek Pada Elbow $90^{\circ}$

\subsection{Membandingkan hasil perhitungan $P 1$ pada pressure gauge dan hasil perhitungan teoritis}

Perbandingan antara P1 pada pressure gauge dan perhitungan toritis berfungsi untuk memastikan besarnya error pada rancang bangun trainer. Untuk membandingkannya digunakan rumus:

$\mathrm{P} 1=\gamma Z_{2}+\frac{1}{2} \rho\left(V_{2}^{2}-V_{1}^{2}\right)+f \gamma \frac{\ell}{D} \frac{V_{1}^{2}}{2 g}+\sum \rho K_{L} \frac{V^{2}}{2}$

Dengan menggunakan salah satu sampel pada bukaan penuh :

1. Tekanan (P1) pada pressure gauge sebesar 2 $\mathrm{kg} / \mathrm{cm}^{2}$

2. Tekanan Teoritis sebesar $1,5 \mathrm{~kg} / \mathrm{cm}^{2}$.

Maka error yang didapatkan sebesar $13 \%$

\section{Simpulan}

\section{SIMPULAN DAN SARAN}

Pada penelitian ini disimpulkan bahwa:

1. Karakteristik debit yang didapatkan bervariasi dan mengalami penurunan sesuai dengan besarnya bukaan katub gate.
2. Koefisien gesek pada setiap titik pengukuran didapatkan semakin naik seiring dengan menurunnya bilangan Reynold.

\section{Saran}

Saran yang didapatkan dari penelitian ini adalah sebagai berikut:

1. Untuk penelitian selanjutnya dilakukan variasi suhu air yang masuk.

2. Penelitian berikutnya digunakan manometer untuk tambahan pengukuran tekanan.

\section{Reference}

Februarman, dkk. 2005. Diktat Praktikum Hidrolika. Universitas Andalas Padang.

Fox, Robert W., and Mc Donald, Alan T. 1994. Introduction to Fluid Mechanics, $4^{\text {th }}$ Edition. John Wiley and Son, Inc.

http://id.wikipedia.org/wiki/Pipa_(saluran), diakses 25 Maret 2015

Munson, Young, Donald F., and Okishi, Thedore H. 1996.Mekanika Fluida. Erlangga, Jakarta.

Munson, Young, Donald F., and Okishi, Thedore H. 2011. A Brieft Introduction to Fluid Mechanics, $5^{\text {th }}$ Edition.John Wiley \& Sons, Inc.

Adiwibowo, Priyo H., dan Sakti, Arya M. 2015. Rancang Bangun Alat Ukur Kapasitas Air Sungai Sistem Portabel untuk Pemetaan Potensi Pembangkit Listrik Tenaga Mikro Hidro (PLMTH). UNESA. 